\title{
Feminism and the New >Mediated Maternalism: Human Capital at Home
}

The status and role of feminist theory is perhaps more vexed than ever, as the university system as a whole finds itself subject to the endless revolutions of the new managerialism which requests of us all new forms and modes of accountability. For example we increasingly have to show evidence of employability strategies incorporated into everyday pedagogic practice. The logistics that this entails inside the feminist classroom is formidable unless one is indeed teaching within a framework of liberal feminism, which would of course emphasise goals and competition and leadership all of which are compatible with models associated with business schools. Where it is possible to have a glimmer of how this may look from a feminist social science background, the question of how the arts and humanities measures up to these new benchmarks is more protracted. (We could ask, "what is the employability quotient of knowledge of sgender performativity theory«?). Nevertheless one cannot ignore such imperatives, or rather only at your peril. But what are the employability strategies that could be deduced from feminist theory, for the vast majority of students who will not be proceeding as the next generation of academics through the $\mathrm{PhD}$ system? Of course the standard answer would be one which would emphasise the general enhancement of social understandings of gender and sexuality which are surely important to young women as they navigate their way through all the issues thrown up by careers and domesticity, by desires for the successes which have previously been promised through the idea of hard work and achievement in school and university, and the jolt of surprise experienced when this element of the snew sexual contract is seemingly thrown into jeopardy when it comes to looking after small children and remaining on the career track. And when we factor in the volatile and unpropitious economic climate there is an additional layer of anxiety about labour markets, about holding onto jobs or about becoming self-employed with all the demands of long hours such an option requires. With all of these issues to contend with for young women in contemporary society, we might imagine that the theories generated within academic feminist research are all the more needed.

In this article I continue some of the themes developed in my book Top Girls (2010) extending debate into the realm of maternity. If the position from which I write continues to reflect a thicket of concerns and tensions seemingly emanating from Anglo-American worlds, my aim is to utilise this as a site ripe for analysis, for what it bodes, not insofar as all things instructive start from this 
corner of the world. By using the phrase biopolitical-conjuncture in a cultural and geographic way, this expanse of space and its hyper-mediated conversations about itself convey further insight on the powers of luminosity, which are now directed towards family and maternity. In addition, I will suggest that current imagery around new norms of motherhood extend elements of the spost-feminist masquerade of which I speak at length in Top Girls. In the book I delineate post-feminism as a constellation of power which pre-empts possible recurrences of feminism by absorbing some of its elements, which in turn can be used to replenish and appear to update the fields of gender and sexuality, meanwhile there are strenuous efforts of disarticulation undertaken to ensure the unviability of a new feminism. Of course such efforts do not necessarily succeed. New forms of feminism do creep up and lodge themselves within the interstices of public life and its institutions, but my task as I see it is to dissect those attempts to fully dominate and regain control of the terrain of sexuality and family life. It maybe comes as no surprise in this regard that I refer extensively to the power of the media. I also ponder the ways in which this particular apparatus (or what Althusser would have called ISA, Ideological State Apparatus) is in possession of a profound weightiness, while always suggesting simultaneously a certain lightness, even a triviality, such that aspects of the magnitude of its power rests on the very ability to constantly undermine itself, dissemble and seemingly divest itself of powers on the basis of providing various services which run the gamut between news and entertainment (Althusser 1971). In what follows I offer short commentaries on feminism, maternity and welfare regimes and the new biopolitics of the (Western) family.

\section{Feminism and the Era of Social Democracy}

The origins of welfare regimes from the early $20^{\text {th }}$ century and especially accelerated in the immediate post-war years, had as a key focus of attention family life predicated on a male breadwinner model. However only in the 1950s did (predominantly white and middle class) women stay home to look after children and remain dependent on the salary of the husband. Welfarism in the UK was associated with the years of social democracy when, in and out of government, the Labour Party exerted a powerful force in public as well as private life. The war effort had drawn women into the workforce and with this the instigation of full-time nursery places for pre-school age children. Through the 1950s this was reversed and social policy re-emphasised the virtues of women as full-time mothers, an ideal taken up and embraced by the hugely popular and widely read women's magazines of the period.

Twenty years later one of the strongest feminist groupings to emerge in Britain tended to self-describe as socialist-feminist although this label included a spec- 
trum of Labour Party-oriented feminists as well as those who counted themselves as Marxist-feminist. Two key texts of this period reflect exactly the terrain of debate, Denise Riley's War in the Nursery (1983) and Michele Barrett and Mary McIntosh's The Anti Social Family (1982). Riley's rich historical account charted the angry debates that raged within the ranks of the medical experts and other professionals about the role of nursery care, and this in turn brought to the attention of feminists the idea of ssocialised childcare something also associated with Communist states. This idea found favour within different strands of feminism for various reasons, first that only full-time nursery care freed women to enter employment, gain economic independence, and pursue uninterrupted careers thus fulfilling their potential as equal to men in work and in professional life, second that the nursery environment was beneficial for children allowing them to gain social skills and escape the over-heated and exclusive emotional connection with the mother, and third that exclusive motherhood was in any case a trap for women, an exhausting, unrewarding role, one of servitude without pay. I emphasise the case of nursery provision because it has remained a key feature of both feminist discourse and of wider public policy discussion for more than forty years. Labour governments have seen nursery care as a way of improving the health and well being of children from poor families while also allowing women to work and hence contribute to family incomes. During the Blair years the Sure Start programme invested millions of pounds in creating a wide network of nursery provision for this very purpose. While feminist theorists through the 1970s, 80s and 90s also pointed to the policing role of welfare especially as it intruded into the lives of working-class families, there was nevertheless a consistent support for state-provided nursery care such that it could be said to be a defining feature of feminist politics, as it still is today.

The Anti-Social Family is also instructive not just because it tackles the oppressive aspects of domesticity and the styranny of maternity but because it acknowledges the exclusions for lesbian women who at the time had few possibilities for maternity and who also suffered the stigma of childlessness. In many ways The Anti-Social Family articulates the divide between the perceived privileges of heterosexual feminism and its trumping of motherhood as a priority within feminism, and the pre-queer dynamics of marginalisation from normative family life. At the same time authors Michele Barrett and Mary McIntosh fully recognise the apparently endless popularity of the family in everyday life and the unlikelihood of its demise. In the light of this seemingly consensual enjoyment of the domestic sphere, feminists arguably withdrew from extreme anti or alternative-family positions (as communal living disappeared) and instead became involved in campaigns which supported mothers through a range of measures notably maternity leave, flexible working hours, as well as access to affordable childcare. I stress this historical trajectory not as an uninterrupted pathway but rather to emphasise the troubled but nevertheless anchored connection between 
feminism and the pro-active policies associated with social democratic governments which supported women's movement into work from the early 1970s onwards and concomitant with this recognised preschool childcare as socially as well as financially beneficial. My question for today, so many years after the moment of feminist nurseries and the demystification of motherhood, is, what place is there for a sexual politics of family life in times of post-feminism, and when social democracy has entered into abeyance to be replaced by formerly leftist parties embracing various third way and anti-welfare pathways? Indeed one could say the European social democratic `ball was set rolling in this regard by the Blair government in the UK and the Schröder leadership in Germany, while of course we can attribute the key momentum from the Clinton years in the US when he professed to change the face of welfare ras we know it火. The question then is how can social democracy be re-invented for today without simply relying on arguments from the past that seem no longer to have wider appeal or currency? The intense familialism of the present moment is compounded by not just cuts to welfare but also by the demonization of welfare as though to suggest that relying on support or subsidy is somehow shameful. At the same time there is a widely disseminated discourse, which celebrates choice and the privatisation of childcare through the use of nannies for childcare. The granting of marital and parental rights to lesbian and gay couples has consolidated a kind of hermetic ideal of family life which undercuts the older social democratic systems of provision for families outside the family such as youth clubs, girls groups, and a wide array of leisure facilities such as municipal swimming pools, tennis courts, libraries and community centres.

\section{The Biopolitics of the Family}

Nuclear familialism is one of the key cornerstones for Western modernity, and something that in times of extreme change and economic anxiety has even greater weight attached to it. The last thirty years in the West have seen the increasing emancipation of women and their entrance into labour markets, and along with this new patterns of migration and flows from under-developed countries entailing various forms of border-crossing which also have repercussions for family formation at both exit and entrance points. If we take both of these factors into account we can see why dominant norms of familialism come under strain. There is a limit to how far governments and political parties can go in terms of castigating the swrong kinds of familys (in the UK low income, often black, single-parent households) without risking widespread social disapproval, and so they must find more subtle means of managing family life. Sociology has provided great insight into the spolicing of families but much of it is also now quite out of date and in need of renewal. With a good deal more space 
needed to expand on this whole terrain of analysis, I will pose a truncated argument as a preliminary discussion point. This says that new ways of instilling updated norms of middle-class family life in the light of the above changes and also taking into account the current economic recession are to be found within the realm of 'media governmentality what is unsayable or undoable in political culture finds ample expression in popular culture, e.g. naming and shaming of poor families with stoo many children', talk about crime-prone families, or the public castigation of bad mothers or unemployed families who are reliant on benefits which can seemingly bring their income to above that of hard working familiess. In this realm working class single mothers find themselves particularly demonised for their multiple failings in the new more punitive scale of normative femininity. In particular their bodies and visual appearance are subjected to harsh and cruel judgement and public condemnation ${ }^{1}$.

We gain a deeper understanding of these processes by reminding ourselves of some key works in this terrain. Donzelot's writing on the family (influenced by his French colleagues including Foucault and Althussser) drew attention to social concerns about poor, working class women in $19^{\text {th }}$ century France abandoning their babies with the costs for the care of abandoned babies having to be found by the municipal councils (Donzelot 1979). Alongside this were concerns about the defective care provided by working class women and wet nurses in the employment of middle class women. Under such arrangements the quality of young persons required for the leadership role of the newly powerful middle classes could not be relied upon. Consequently new ideas about maternity and citizenship began to circulate which saw especially the middle class woman gain new status and influence on the basis of her skills of household management and the care and upbringing of children. (Donzelot discusses here a new semi-professional conversation established between middle-class mothers and the medical profession). The push then was to instil high standards of middle-class family life, something that found expression in the rise of instructive women's magazines.

Donzelot foregrounds the moral status of domesticity as exemplified only within the comforts of the middle class home. By these means, class antagonisms and the consolidation of middle class power comes to be played out in the realm of the home through the deployment of an ever more complex range of sdividing practices. Donzelot describes the key role attributed to women in pursuing these class antagonisms, and how socially valued norms of feminine-

1 A current case involves a mother (pictured with pink-dyed hair) of 10 children for whom the local council is now building a new 6-bedroom home for her family. Apart from the moral outrage at the cost to the taxpayer etc., families like this are condemned as unruly, disorganised, chaotic, crime-prone, with the over-fertility of the mother at the heart of such social disapprobation. 
maternity came to be inscribed within this landscape of middle-class life. From this perspective working class mothers could only feel themselves to be defective. It was not until many years later, that the respectability of femininity came to be understood as a disciplinary instrument directed towards the always inevitably failing bodies of working class women (Skeggs 1997). Foucault, in his 1970s lectures, provides some remarkably interesting insights as to how these dividing practices were also connected with the new political economy of neoliberalism (Foucault 2006). Looking back to the influential ideas of the OrdoLiberal School and especially the work of Roephe, Foucault shows how notions of family and of good housekeeping came to be associated also with national economies and with the idea of enterprise. Here too the whole life of the middle classes has to be seen as a moral force for good, if the power of the working class movement has to be scuppered. One way of trying to >de-proletarianise< (as Roephe put it) society, was by casting the ideal family as a kind of small business unit, which in turns means that a business ethos at home, rather than a rowdy and truculent working class culture, is promoted once again to girls and young woman as a morally superior way to live. This good housekeeping metaphor is routinely extended into matters of state and national economy right up to the present day. It is a favourite expression of the German Chancellor as it was of Mrs Thatcher (who by the way famously said there is no such thing as society, only the individual and his family $)$.

These various technologies of power took the form of explosions of discourse through early mass media and popular culture directed at working class women and girls. It was they who could be targeted and taught to yearn for norms of middle class respectability and consumer culture. Foucault highlights family life at the heart of the neo-liberalisation process by reminding us of how careful calculations are made in terms of investing in the human capital of the child as an rabilities machiner. The family as enterprise is also, within contemporary postwelfare discourse, one-way of re-traditionalising gender as though by the back door. The family becomes a kind of unit or team, a partnership of equals, and new visibilities show stay home Mums and full-time working fathers, but in contemporary times this is a team decision, one which could be easily reversed, and so by emphasising personal choice it evades the criticism of merely being a return to the past, indeed it is a very modern solution.

We could summarise these shifts along the following lines. New norms of middle-class life directed especially towards young women require a more intense investment in marriage, motherhood and domestic life, as a benchmark of successful femininity. This validates at least a retreat from the idea of combining full-time successful careers with motherhood, indeed it gives new, more professional, status to full-time mothers while opening up avenues for extensive media discussion of intensive mothering and at the same time creating new markets (child-friendly coffee shops and so-called sschool run fashion 
syummy mummies. These markets also extend to push-chairs which double as jogging machines, sexy underwear ranges for pregnant women (see Tyler 2011), new parenting magazines funded by advertisers (in Germany Nido) as well as a host of website organisations (like www.mumsnet.org), which also inaugurates new realms of consumption through the range of activities and products it recommends.

This whole scenario also entails an expansion of Foucault's idea of calculation within family life as young women are endlessly prevailed upon to plan well for marriage and family life including finding the right kind of partner with an appropriate income. Such practises do not extend to men, giving rise to the re-appearance of old gender stereotypes that see men as a >catch their mothers as predatory husband-seekers. In this scenario, marriage is nevertheless seen as a partnership of equals (with feminism taken into account) while such progressive changes are conveniently used to validate flexible normativity. Therefore the dispositif of new maternal-familialism is inextricably tied up with expansive norms of respectable middle-class life, which in turn entails careful financial planning, good self-governance to insure against family breakdown, along with the increasing professionalization of motherhood which sets new horizons for middle-class status on the basis of aspirational lifestyle, non-reliance on the state or on benefits and a female head of household who can sdo it alk even if she cannot quite shave it alk. The idea of spost-feminist masquerade is once again useful as a way of understanding a mode of power, which installs notions of female perfectability within the field of maternity. And, as before, there is frequently some irony and ifeminist self-consciousness in the recounting of the rewards of good housekeeping. The UK popular (and quality) press (and occasionally also TV) functions as the debating chamber for these maternal transformations, the luminosities of visual culture show again and again, day in and day out, the triumph of the spost baby body`, or the favoured looks for the sschool run, the modern woman is not that namer unless she is in possession of a well-dressed toddler or mini mer. Motherhood no longer offers a short timeoff period of respite from those forms of social power which comprise incitements and persuasions to get back in shape and to resume the work of achieving the highly sexualised body image which is now a hallmark of successful womanhood. The post-feminist masquerade of maternity re-assures the social structures of domination by constraining young mothers in a field of anxieties brought about by the promise of scomplete perfection< (Riviere 1926/1978). This luminosity of contemporary femininity shines its light unsparingly, its significance stretches well beyond the pages of the women's magazines because at stake in these practices are matters of state, undertaken within the new moral economy of the family. 


\section{Literatur}

Althusser, Louis (1971): Ideology and Ideological State Apparatuses. In: ders.: Lenin and Philosophy. New York.

Barrett, Michelle / McIntosh, Mary (1982): The Anti-Social Family. London.

Donzelot Jacques (1979): The Policing of Families. New York.

Foucault Michel (2006): The Birth of Biopolitics. London.

McRobbie Angela (2010): Top Girls. Feminismus und der Aufstieg des neoliberalen Geschlechterregimes. Hrsg. von Hark, Sabine / Villa, Paula, Wiesbaden.

Riley Denise (1983): The War in the Nursery. London.

Riviere Joan (1986) [1926]: Femininity as Masquerade. In: Burgin, V. / Donald, J./Kaplan, C. (Hrsg.): Formations of Fantasy. London.

Skeggs Beverly (1997): Formations of Class and Gender: Becoming Respectable. London.

Tyler I. (2011): Pregnant Beauty Maternal Femininity under Neoliberalism. In: Gill, R. / Scharff, C. (Hrsg.): New Femininities. London. 